\title{
Going with the grain: Mobile devices in practice
}

\author{
John Pettit and Agnes Kukulska-Hulme \\ The Open University
}

\begin{abstract}
Fifty-seven alumni of a global Masters program participated in research into their use of mobile devices. Drawing on questionnaire and interview data, the paper examines how far the devices were embedded in the personal and professional lives of these alumni, most of whom were aged 35-54. All had experience of online and distance education, and most worked in education or training. The study revealed some innovative uses of mobile devices, a selection of which is reported in this paper. The paper links the findings to wider debates about the changing relationship between learners and educational institutions, and the role of mobile devices in enabling individuals to engage in learning conversations. Data are provided on which devices were used by the alumni and for what purposes, and the paper explores the implications of these findings for educators.
\end{abstract}

\section{Introduction: The importance of context}

Mobile devices have engaged the imagination of a number of educators, not least because such devices are a significant part of the grain of daily life. Armatas, Holt and Rice (2005), for example, argue that the nearubiquity of the mobile phone gives it powerful potential for supporting online learning at Deakin University. They suggest a number of uses - such as providing off-campus students with 'audio augmented feedback on assignments' (p.31), or pushing a welcome-message to new students' mobile phones.

In a different continent and context, Tamminen, Oulasvirta, Toiskallio and Kankainen (2004) envisage the potential of context aware computing for helping Finnish city dwellers to manage their everyday travel. They outline ideas such as a device that vibrates as the bus approaches, or that suggests a quicker route to enable a passenger to recoup time spent on an unscheduled chat with a friend. They argue that, through its focus on 'mundane doings in particular mobile circumstances' (p.136) - in this case, the journeys of twenty-five inhabitants in Helsinki - their study can give insights into powerful uses for mobile devices in a particular context. 
The two settings and activities - learning at Deakin University, and navigating in Helsinki - have obvious differences. But in both papers there is an emphasis on threading innovative uses of technology into the existing fabric of behaviour. In Armatas et al. (2005) this approach is more implicit and pragmatic: since mobile phones are widely used, it seems logical to attempt to harness them for teaching and learning. And since students often request downloadable lectures to play on a mobile device, it makes sense for the university to provide them. In Tamminen et al. (2004) the approach is elaborated and explicitly ethnomethodological, focusing tightly on patterns of apparently mundane travel-related actions in a 'geoculturally bound' context (p.142).

Yet in both papers there is a broadly user-centred approach. This is captured where Armatas et al. argue that, in influencing the university to provide downloadable lectures, students are 'shaping and driving the technology agenda' (2005, p.28). Mobile devices, contrasted with the centralised university-wide infrastructure for online learning, come to symbolise a greater focus on students and users, on the 'small, mobile and local' (ibid.).

These themes - uncovering patterns of use, and trying to work with them provide part of the framework for the study reported in the current paper. Drawing on responses from 57 distance education alumni, many of them older than the iPod generation, the authors explore and analyse how the respondents exploit mobile devices - mobile phones, smartphones, PDAs and MP3 players - for learning, teaching, work, social interaction and entertainment.

Many of the contexts reported here are informal and personal, while some derive from work and formal teaching. Some responses are tightly related to a particular setting, while others appear to be widely transferable. Many relate to teaching and learning - the teaching of music or languages, working with adults with learning difficulties, or the pursuit of an interest in photography that ends up celebrating, in the words of one respondent, 'the joy of social interaction'. The study goes some way to uncovering the grain of participants' use of mobile devices. More specifically, it throws light on some of the detailed choices that individuals make, why they adopt some patterns of use and not others, and how this illustrates the importance and complexity of context' to which Sharples, Corlett and Westmancott refer (2002, p.233).

The study also illustrates and analyses novel applications in the territory between formal and informal learning, and pushes further into the question of whether mobile devices - through their association with recreation, communication and fun - have a particular motivational power 
that can be harnessed for learning. This relates to work by Schwabe and Göth (2005), for example, in their study of a mobile orientation game for new students at Koblenz University. Most students reported high levels of enjoyment, and findings such as this encourage Schwabe and Göth to aspire to tap the attraction of gaming so that the classical dichotomy between fun and learning may be closed' (p.215).

Tapping into deeply felt motivations, and the elision of dichotomies, also informs the other major theme explored in this paper - the use of mobile devices for both creating and 'consuming' online content. Several of the respondents in the current study indicated that, using mobile devices, they are creators and/or consumers. The findings give a perspective on some of the claims about trends in education and media that are set out in the next section of the paper.

\section{Who's powerful now?}

Under a title that was deliberately and ambiguously apostrophe-free - 'The students own education' - Downes (2006) argued that we are moving to a situation where students 'produce their own content'. He cited the high volume website MySpace, where vast numbers of users - often in their teens - blog, publish personal profiles and upload photographs. This impulse to create and publish content - in MySpace and many other social networking websites - has profound implications, Downes argues. Insofar as some of the content on the web is 'educational', and insofar as users access it, the trend underpins the move towards personal learning environments where students can 'access learning from a variety of sources'. If this happens, institutions lose much of their control over content and over the learning environment, while learners - as agile consumers and creators - take greater ownership.

This question of ownership elaborates one of the themes of the ascilite conference - not only 'Who's learning?' but 'Whose learning?' To explore those questions, higher education may benefit from considering the media industry, where business models appear to be undergoing profound change - with, again, a shift towards the user. The questions could be rephrased as 'Who's writing? Who's paying?' The UK newspaper website Guardian Unlimited, for example, publishes talkboards of readers' comments alongside content that its staff create especially for the web, plus stories that have been published in that morning's newspaper.

This is less radical than Downes' vision: rather than having innumerable webpages created by countless users, Guardian Unlimited provides defined and branded spaces - such as the one titled 'comment is free' - where readers post responses. And rather than the users creating all the content, 
Guardian Unlimited demonstrates that there is still a place for sharp, professionally written stories. What is more radical is that the website demonstrates not only that comment is free, but that much content is too. While the ink on paper version has a cover price, much of the website can be accessed without payment. Yet, because of advertising revenue, it is reported to be commercially successful (Day, 2006).

There are implications here for higher education. If personal learning environments transform education in the way that Downes suggests, learners will access each other's content and break free of a 'centralised, institution-based system depending on a top-down structure and rigid standards' (Downes, 2005). In that case, what role - if any - remains for institutions and their systems? Will academics, perhaps roughly equivalent to the Guardian's journalists, continue to be paid to produce some learning content? And will universities, if at least some of their teaching becomes open content as at The Open University (UK) and elsewhere, be able to recoup their costs - perhaps not with advertising revenue but with some other model of charging?

Finding a new model may be essential for educational institutions' survival, a point made by Heppell (2006). He sees power as having moved towards the learner so that the relationship with universities is now symmetrical. The point from Armatas et al. (2005) quoted earlier, that mobile phones are to some extent a counter to the centralised system, is consistent with this. In the context of this symmetry, Heppell asks (2006) how universities can 'move from being a big thing that did things for people, to being part of that agile, viral, peer-to-peer conduit of help and self-help and esteem and exchange'.

One way forward, he suggests, is to foster online communities of learners. Such an approach will be very familiar to university teachers, whether on campus, online or using a blend. Even the delights of Web 2.0 may not be as new as is sometimes thought. Lilley (2006), for example, has argued that '[i]f the blog has a common ancestor with the diary, MySpace shares at least some of its DNA with the scrapbook'. Nevertheless there is an obvious change of scale from diary and scrapbook to blog and MySpace, and individual users and learners now have vastly greater power to publish and access content.

The shift of power away from large institutions is hardly a new issue. Discussions of education in a post-Fordist future have envisaged that students would 'browse the global market' in their search for education (Pettit, 1998, p.250). But in the 1990s the question was usually whether the mega-universities, said to be locked into Fordist rigidities, would be agile enough to compete with smaller conventional universities and with the 
'new all-electronic institutions' (Bates, 1997, p.102). That question regardless of how it was going to be answered - still assumed that institutions of some kind would provide the education and content. Downes, in contrast, is suggesting something more radical, which appears to have long roots back to the free universities of the 1960s. This is a very different world in which mobile devices need to find their place.

\section{The mobile promise}

Within this context, mobile devices appear to offer a further strand of liberation and flexible learning. Cochrane, for example, has written of the potential for an m-learning 'revolution' (2005, p.156). Mobile devices are highly personalised, yet enable us to share ideas and information with others, and they promise access at any time from any place. They allow us to feed off the wifi environment for survival information such as travel updating, and to enrich the experience of visiting a museum (Mulholland, Collins \& Zdrahal, 2005). Moreover, companies spend a great deal of money on making them attractive.

There are several advantages implied: that individuals will engage in learning at times when formerly they would have been doing something else; that they will be motivated to learn partly because the devices are attractive; that the devices enable communication from places where formerly it wasn't possible; that formal learning can mesh with existing patterns of self publishing and online participation; and that mobile devices are particularly suited to multitasking, said to be one of the strengths of the 'millennial generation' (McMahon \& Pospisil, 2005).

Of course, work remains to be done as teachers set out to integrate mobile devices into specific contexts of education. Corlett, Sharples, Bull and Chan (2005), for example, evaluated MSc students' use of a mobile learningorganiser that had been installed on a wireless enabled device. Small screen size, short battery life and limited memory were reported as significant problems. Thornton and Houser (2005) reported a study of 44 Japanese students who received small chunks of English vocabulary teaching material on their mobile phones. Different chunks were sent out three times a day in the hope that students would study each chunk as it arrived. The authors report considerable success but note that over half the students did not engage in this 'carefully timed interval study': they saved the chunks for one time of day when they could concentrate on them in a batch (p.222). Clearly the mantra of 'any time, any place', even when technically feasible, does not always mesh with the way people integrate mobile devices into their lives. The next section sets out how, in the current study, the authors explored the issue of integration, looking at which devices the participants used, and in what ways. 


\section{Methodology}

\section{Participants}

The participants were registered alumni of The Open University's Masters in Online and Distance Education, a global intake program developed by the Institute of Educational Technology (where the research was carried out, and where the authors of this paper are based). The alumni had completed at least one-third of the program, and in some cases all of it. Although innovatory practice in e-learning is an important feature of the program, it was not assumed that the alumni would necessarily include those for whom '[v]enturesomeness is almost an obsession' (Rogers, 2003, p.282). It seemed likely, though, that they would include those with valuable and interesting experience of using mobile devices - whether for formal or informal teaching and learning, work, social interaction or entertainment.

Of the 150 alumni who were invited, 57 (38 per cent) completed the online questionnaire - the first stage of the research. The questionnaire was administered anonymously, but respondents were invited to identify themselves if they were willing to take part in a follow up interview. Thirty-one did so, and nine were interviewed.

\section{Method: Online questionnaire}

The purpose at this stage of the research was to gather both numerical and qualitative data on the breadth of participants' use of mobile devices: which did they use, for what activities, and how? Participants were asked whether they had used a mobile phone, smartphone, PDA (personal digital assistant) and MP3 player (for example, an iPod). For each device, they were asked whether they had used it for teaching, work, learning, social interaction, and entertainment (including quizzes and games). And for each activity they selected, they were asked to give an example.

This pattern of questions was designed to prompt participants about devices/usage. While this may have reminded them of usages they would otherwise have forgotten, it imposed a set of categories on their responses. To mitigate this, participants were invited to include informal uses (with friends, family or interest groups) when responding about their 'teaching' and 'learning'. There was also a catch-all question about any other uses, and in addition participants were asked how often they carried out specified activities with a mobile device, such as reading an e-book, browsing a website, or making a video clip. 


\section{Method: Interviews}

The nine interviewees were chosen principally because their questionnaire responses suggested they were engaging in interesting/novel applications, but also to include some participants from outside the UK. The approach was not intended to uncover uses that were representative of the cohort, and indeed it probably skewed the data towards those with most experience of, and interest in, mobile devices. Nevertheless, interviews gave the opportunity to capture details of individual accounts and contexts, to move outside the categories of the questionnaire, and perhaps to capture innovative practice.

Although this broadly phenomenological approach might deliver detailed stories, it was not assumed that an interview could deliver an 'objective' account or even, at the other end of the scale, an 'authentic' one. Both interviewers and interviewees draw on their conceptions of what an interview ought to be. Holstein and Gubrium, for example, argue that interviews are 'collaborative accomplishments' between interviewer and respondent (2004, p.141). And in the stages of making a narrative of the interviewee's experience, gaps open up - what Miller and Glassner call 'fissures from the ideal text' (2004, p.127). The transcription of a recorded interview is one such fissure: in the current study, seven of the interviews were carried out by phone, recorded and transcribed, and two interviews were carried out by email.

If any interviewees had still been studying the Masters program, their scripts might have come to examination boards chaired by the authors of the current paper. It was necessary to preserve anonymity, therefore, and all interviews were carried out by an experienced researcher and transcribed by an administrative assistant. The authors were not informed even of the gender of the interviewees - hence the use of ' $A$ ', ' $\mathrm{B}$ ' etc, rather than pseudonyms, in the reporting and discussion below.

\section{Questionnaire results}

\section{The respondents}

About three-quarters of the respondents were aged 35-54 and a little over half $(55 \%)$ were female. Over half lived principally in the UK, with most of the remainder living in continental Western Europe, and 5 living in Hong Kong, Japan, Peru and the USA. Nearly all described their profession as associated in some way with education or training. Table 1 indicates that, although almost all respondents reported that they had used a mobile phone, only about half stated they had used a PDA or MP3 player. The picture in this area is continuously changing, and the data in the table 
(these were obtained in 2005) are inevitably a snapshot. Note that the figure of $18 \%$ for those who had used a smartphone may include respondents who had also used a mobile phone.

Table 1: Respondents' usage of mobile phone, smartphone*, PDA and MP3 player

\begin{tabular}{|l|c|c|c|}
\hline 'Have you used a... & no response (\%) & Yes (\%) & No (\%) \\
\hline ...mobile/ cell phone?' & 2 & 95 & 4 \\
\hline ...smartphone?' & 2 & 18 & 81 \\
\hline ...PDA?' & 2 & 46 & 54 \\
\hline ...MP3-player?' & 2 & 52 & 48 \\
\hline
\end{tabular}

Note. $n=57$. Because of rounding up, totals exceed $100 \%$;

*defined in the questionnaire as 'mobile phone/PDA in one device'

Of those who had used a mobile phone, $96 \%$ reported using it for social interaction, and $78 \%$ for work. Outside these uses, the figures were much lower: 30\% for teaching; 19\% for entertainment, quizzes and games; and $17 \%$ for their own learning. Although the respondents may not have found the categories clear-cut, the reported differences in use are interesting and are discussed below. The questionnaire data are also reported and discussed more fully in Kukulska-Hulme and Pettit (2006).

Table 2 gives the relative frequency of various activities involving mobile devices. The prevalence of text messaging is not surprising; but it is worth noting - and will be picked up in the discussion below on use of content that about one-quarter of respondents reported that they accessed websites at least once per week. This frequency (though not necessarily the amount of time spent) is nearly as high as for listening to an audio file.

\section{Disadvantages for own learning}

When asked to state one or more disadvantages of mobile devices in relation to their learning, 15 respondents cited usability problems (with small screen size the most prevalent). Technical difficulties (for example, short battery life) were cited 11 times, accounting for most of the remaining responses. Similar usability and technical difficulties have been reported in Kukulska-Hulme (2002) and Waycott and Kukulska-Hulme (2003).

\section{Interview data}

The nine accounts were analysed in relation to a number of issues raised in the introduction: 


\section{Context (travel)}

Interviewees ' $A$ ' and ' $B$ ' reported that changes in the travel environment had had an impact on their choice of device. One spoke of the benefits of an MP3-player over a book, 'especially as [bus companies] are converting to standing-up buses'. For the other, a new style of seating on trains meant it was difficult to accommodate a laptop, whereas a PDA was 'fantastic in those circumstances'.

\section{Device choice}

Interviewee ' $C$ ', living in a city where free wireless access is widely available, reported 'huge dependency' on a laptop; the mobile phone had been relegated 'just to taking phone calls'. Once interviewee ' $\mathrm{D}$ ' learned to type well, the laptop's keyboard became particularly beneficial, whereas for ' $B$ ' the PDA was 'something I am never without', even on holiday.

Table 2: Respondents' frequency of participation in various activities with mobile devices

\begin{tabular}{|c|c|c|c|c|c|c|c|}
\hline & $\begin{array}{l}\text { No } \\
\text { resp- } \\
\text { onse } \\
(\%)\end{array}$ & $\begin{array}{l}\text { Never } \\
(\%)\end{array}$ & $\begin{array}{l}<1 \text { per } \\
\text { month } \\
(\%)\end{array}$ & $\begin{array}{l}1 \text { per } \\
\text { month } \\
(\%)\end{array}$ & $\begin{array}{c}1 \text { per } \\
\text { week } \\
(\%)\end{array}$ & $\begin{array}{c}\text { A few } \\
\text { days } \\
\text { per } \\
\text { week } \\
(\%)\end{array}$ & $\begin{array}{c}\text { At least } \\
\text { once } \\
\text { per day } \\
(\%)\end{array}$ \\
\hline $\begin{array}{l}\text { Browsing mobile (WAP) } \\
\text { websites }\end{array}$ & - & 56 & 18 & 2 & 11 & 11 & 4 \\
\hline $\begin{array}{l}\text { Browsing 'ordinary' } \\
\text { websites }\end{array}$ & 2 & 56 & 14 & 5 & 2 & 5 & 16 \\
\hline Reading e-news & - & 51 & 14 & 7 & 5 & 14 & 9 \\
\hline $\begin{array}{l}\text { Using a location based } \\
\text { service* }^{*}\end{array}$ & 2 & 67 & 9 & 11 & 9 & 4 & - \\
\hline $\begin{array}{l}\text { Sending text messages } \\
\text { (excluding Bluetooth } \\
\text { use) }\end{array}$ & 2 & 16 & 5 & 5 & 16 & 19 & 37 \\
\hline Reading an e-book & 2 & 65 & 16 & 5 & 7 & 2 & 4 \\
\hline $\begin{array}{l}\text { Listening to an audio } \\
\text { file }\end{array}$ & 2 & 44 & 18 & 11 & 4 & 11 & 12 \\
\hline Recording own voice & 4 & 58 & 23 & 9 & 5 & 2 & - \\
\hline Making a video clip & 4 & 60 & 26 & 5 & - & 5 & - \\
\hline $\begin{array}{l}\text { Sending a video clip } \\
\text { from a mobile device }\end{array}$ & - & 86 & 11 & 4 & - & - & - \\
\hline
\end{tabular}

Note. $n=57$. Because of rounding up, some totals exceed $100 \%$;

*defined in the questionnaire as 'e.g. to find nearby taxis, bank, restaurant etc'

Size matters, not surprisingly, in the choice of device: for interviewee ' $E$ ', PDAs were rejected in favour of a laptop (bigger keyboard) and a mobile phone (smaller device). The two selected devices supported each other: 
when ' $E$ ' was travelling, s/ he set the mobile phone to bleep when an email arrived and, though ' $\mathrm{E}$ ' might read an email on the phone, s/he usually typed a reply, at a later point, on the laptop.

Speed can also matter: for language learning, 'B' preferred a PDA over handwriting because it was slower: $\mathrm{s} /$ he argued that this led to more careful thinking before writing, a 'distillation process' (in addition to avoiding the need for transcription later).

\section{The attraction of the mobile phone}

Interviewee ' $\mathrm{I}$ ', a teacher of Spanish, had asked pupils to send text messages in Spanish to the teacher, who was on a visit to Spain. S/he reported that pupils added personal messages asking about the weather and food, and s/he concluded that some 'believed it was a personal thing, not homework - somehow they do not link the idea of mobiles with classwork'.

\section{Formal settings}

At times, devices were combined in ingenious ways to support formal learning. Interviewee ' $\mathrm{B}$ ' selected a brand of PDA with a high-quality builtin microphone, for a scheme where s/he was working with music teachers. The device was good for recording pupils' musical performances and progress, and was less frightening than a free-standing microphone. At the same time, the built-in speakers were not good enough for playback, so battery-powered portable speakers were attached. Interviewee ' $\mathrm{B}$ ' also spoke of a colleague who had used an MP3 player at the end of each lesson to record adults with learning difficulties speaking of what they had just done. They could go back at any time and listen to the recordings from previous lessons: 'a fantastic way of getting adults with learning difficulties to sort of reflect on their own learning, and also of course provide evidence for anybody else'.

\section{Content}

Where interviewees reported creating content, it was often for their work or individual study (though most frequently it was text messages). In terms of consuming content, interviewee ' $G$ ' spoke of downloading articles, newspapers and novels to a PDA - to avoid having 'dead time': for this interviewee, it was essential to have material on mobile devices to read while travelling. ' $G$ ' also reported that the PDA had led her/him to keep a diary: 'I don't think I would keep diaries if I didn't have a PDA'. 'E' reported at times using the mobile phone, while travelling, to access news websites designed for mobile devices: 'they have structured their articles for very short paragraphs'. ' $\mathrm{H}$ ' also reported accessing the Internet with a 
mobile phone, and using an MP3 player during frequent travel to listen to audiobooks, podcasts, lectures. The device enabled other activities: 'I take notes, follow up on books, articles and websites mentioned. Sometimes I discuss what I have heard with my co-workers.'

\section{Social networking websites, informal learning}

Interviewee ' $G$ ' reported using a mobile phone to take photographs and post them to a blog. The initial motivation was to keep family and friends up to date when the interviewee was travelling. But this usage evolved: the moblog enabled users to comment on the photographs, and these comments came to represent

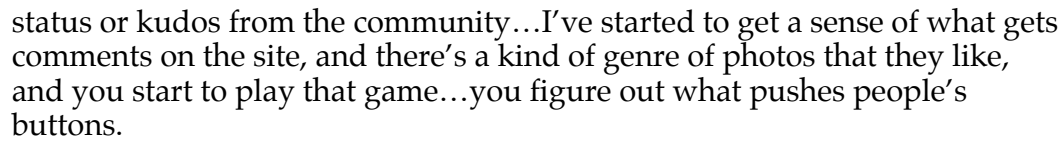

' $G$ ' also had two examples of learning conversations that grew out of the posting of images. In the first example, a female user had noted a poster for a design competition and commented that all the judges were male; this led to a discussion on sexism and design. 'G's second example relates to the London bombings of 7 July 2005:

\footnotetext{
[on the moblog] there were photos of people who were actually there, not some journalist hovering around the perimeter of ambulances. It was there that we first saw that photo of that guy with the cloth over his face at the tube station, and this appeared very, very quickly.
}

The bombings led to a heated political discussion that, reported ' $G$ ', became so engaged that the server overloaded and went down that evening, and I actually learnt quite a bit...'

\section{Discussion}

The study was intended to establish which mobile devices were used by alumni of a Masters program, and for what purposes. The intention was to see how far the devices were embedded in the personal and professional lives of people who had a particular interest in online and distance education (the subject area of this global Masters). Of all the mobile enabled activities that were technically feasible, which did these alumni mainly in the 35-54 age-range - actually decide to engage in? The answers would have implications for educators interested in the use patterns of similar learners, and might also reveal whether the alumni were undertaking new forms of 'learning', however personally and informally that is interpreted. In addition, since many of the alumni were themselves 
professionally involved in education or training, the study might uncover innovative mobile-related practices.

The data indicate that, while nearly all participants had used a mobile phone, only about half had used a PDA or MP3 player. Usage is changing, and data of this kind can only be a snapshot. Nevertheless they suggest that educators need to be wary, when designing educational activity for learners like these alumni, of counting on incorporating access to PDAs or MP3-players.

Of course, with careful design and support, innovative use can be achieved: educators don't have to confine their ambition to what's familiar to learners, and there are reports of success in introducing students to new devices/uses. There are also reports of relative failure, and the current study suggests some of the reasons. One of the distinctive contributions of the interviews was to illustrate how the participants wove particular devices and practices into their daily lives, especially when travelling. The fit appeared to be intense but provisional, and dependent on factors often outside the control of the individual, and certainly of any educator wishing to design learning around smartphones, PDAs or MP3 players. When participants chose or rejected a particular device, they cited a number of unpredictable factors - changes to the design of buses or train seats, for example, improvements in typing skills, whether a device 'looks stupid', or individual trade offs about the value of carrying a larger device in order to gain a keyboard. These findings draw on only a few of the interviews, but are consistent with a number of other reports on the integration of mobile devices into the fabric of daily life.

Some of the interviews indicate the particular importance of travel periods for study, for informal learning, or just for engagement with news and other material. This is consistent with Thornton and Houser (2005): a significant number of the participants in their report used the travel period to access the chunks of language material that had been sent to them at intervals during the day on their mobile phones. For these participants, travelling home was the time when they felt able to study, overriding the carefully paced delivery through the day that the educators had designed. Wray (2006) also emphasises the importance of travel periods for engagement with material on mobile devices. He cites a UK trial, by a phone operator and broadcaster, of mobile television: 'Some users said they had changed their commuting habits so as to catch their favourite shows while on the bus'.

If educators have ambitions to use mobile devices to exploit their learners' commuting time, they will need to examine its patterns carefully. Writing of context aware technologies, Tamminen et al. argue that acceptability 'is 
dependent on how well they fit into the routinely carried out mundane processes of everyday life' (2004, p.142). Educators may not necessarily need to stay within existing patterns of everyday life, but it seems sensible to find out first what those are.

The current study indicates, not surprisingly, that nearly all participants had used a mobile phone. This is a first step towards the position of Prensky (2005) and others who advocate their use in teaching and learning. However, only about one participant in six reported using a mobile phone for their own learning, a lower usage than for teaching, and far lower than for work and social interaction. Designers of learning activities on mobile phones may therefore need to provide initial support to such learners, but intuitively this looks far easier than persuading learners to adopt a new device. And device convergence, if it happens, may mean that new functions - and new educational potential - can be smuggled in under cover of the coolness or convenience of the 'mobile phone'.

The findings on mobile related activities (Table 2) indicate that about one in four respondents used a mobile device to access wap-enabled and other websites at least once a week. This figure is lower than for text messaging, but not much lower than for listening to an audio file. Further research is needed into which sites are accessed, for how long and for which activities. Nevertheless the current study suggests that, for learners like these alumni, accessing websites could become an important use for mobiles.

The data on accessing e-news indicate that, in at least some cases, respondents were accessing sites that provided content. In the activities shown in the table, creating content - for example, recording one's own voice - is markedly less popular than listening to a recorded audio file. This may not be surprising, but it is useful in the context of the debate about content-creation and content-consumption. The data in the table also indicate that one in ten respondents reported using a mobile device to read an e-book at least once a week - again, consuming (usually professionally prepared) content.

In addition to giving insights into device-choice, the interviews provided a vivid account of the use of a moblog - where photographs were uploaded, news captured and discussions initiated. Interviewee ' $G$ ' spoke of the satisfaction of receiving positive feedback on photographs, and this matches the point that Lilley made about his own experience of such a site: '...when someone commented favourably on one of my own [photographs], it was a unique moment' (2006, p.8). In the current study, ' $G$ ' highlighted the role of individuals in capturing powerful and almost immediate images of the aftermath of the London bombings in July 2005. This accords with Owen's argument (2005) that 'the images that defined 
the media coverage of the July 7 London terrorist bombings [...] came not from professional news crews but from everyday people'.

These points lead back to the discussion earlier, on whether there is now greater symmetry between individuals and news organisations, and between learners and institutions, and whether mobile devices have a role to play in this. On the one hand, the power of anyone with a suitable mobile to create content - as exemplified in the current study by interviewee ' $G$ ' using a moblog - seems close to Downes' ideal of users starting to create a personal learning environment. ' $G$ ' created content in the light of feedback, and engaged in conversations that elided the boundary between personal interest and learning.

On the other hand, although Owen may be correct about the role of 'everyday people' in this instance, it is also true that content published by individuals on the web is often inflected with issues of status, sometimes relating to the content, sometimes to the individual. Interviewee ' $G$ ' indicated that some images received 'status and kudos' while others elicited no reaction. Mitchell (2006), writing about the creation of academic blogs, refers to claims that certain blogs are likely to attract far more readers than a paper in a scholarly journal, and are becoming crucial in some fields for academic reputation and status.

\section{Conclusion}

The study was motivated partly by a wish to uncover the ways in which mobile devices were used by alumni of the Masters program. This approach, of looking at the grain of current use, is consistent with that of a number of researchers, including those whose primary interest is context aware computing and who have put a very useful emphasis on the detailed texture of lives in specific contexts. The interviews in the current study, though not ethnomethodological, attempted to engage with some of that detail, and suggest that interviews can be an important source of data to combine with numerical data in this area.

Taking the mobile phone as the most widespread device at present, it is important to study the detail of how it is used, accepting that one group of users may exhibit very different patterns from another. The differing choices of groups, and of individuals within a group, will be affected by a bewildering array of factors, and to some extent these will continue to cut across educators' attempts to harness the near ubiquity, in many parts of the developed world, of this device.

Given this emphasis on actual use patterns, educators may at times wonder whether they should stay within those patterns, or whether they can 
reasonably ask learners to adopt a new device, or at least a new usage of a familiar device. Working with the grain may look desirable but can be restrictive. The most effective approaches are likely to be open to both perspectives - uncovering existing patterns and at times working within them, but at other times seeking to enlarge their scope to enable more ambitious learning.

\section{Acknowledgements}

The authors would like to thank the alumni of The Open University's Masters in Online and Distance Education who completed the questionnaire and took part in interviews. They would also like to thank colleagues from the Institute of Educational Technology: those who commented on the questionnaire in draft; Donna Phillips, who produced and administered the questionnaire; Juliet Padbury, who transcribed the interviews; and Anne Jelfs, who organised and carried out the interviews.

\section{References}

Armatas, C., Holt, D. \& Rice, M. (2005). Balancing the possibilities for mobile technologies in higher education. In Balance, Fidelity, Mobility: Maintaining the Momentum? Proceedings ASCILITE 2005. Brisbane, 4-7 December. [viewed 19 June 2006] http: / / www.ascilite.org.au/conferences/brisbane05/blogs / proceedings/04_Armatas.pdf

Bates, A. W. (1997). The impact of technological change on open and distance education. Distance Education, 18(1), 93-109.

Cochrane, T. (2005). Mobilising learning: A primer for utilising wireless palm devices to facilitate a collaborative learning environment. In Balance, Fidelity, Mobility: Maintaining the Momentum? Proceedings ASCILITE 2005. Brisbane, 4-7 December. [viewed 19 June 2006] http: / / www.ascilite.org.au/conferences / brisbane05/blogs/proceedings/16_Cochrane.pdf

Corlett, D., Sharples, M., Bull, S. \& Chan, T. (2005). Evaluation of a mobile learning organizer for university students. Journal of Computer Assisted Learning, 21(3), $162-170$.

Day, P. (2006). Tangled web. In Business. BBC Radio 4, 15 June.

Downes, S. (2005). Emergent learning: Social networks and learning networks. [viewed 1 July 2006, verified 16 Feb 2007] http:/ / www.downes.ca/ files/osn.html

Downes, S. (2006). The students own education. Presentation on 5 June to the Knowledge Media Institute. The Open University, Milton Keynes, UK. [viewed 3 July 2006] http:/ / stadium.open.ac.uk/ stadia/ preview.php?s=29\&whichevent=798

Heppell, S. (2006). It's a new millennium, it's a new century. Towards a Global Online University. Presentation on 5 June to Strategic Forum, The Open University, Milton Keynes, UK. [viewed 22 June 2006] http:/ / stadium.open.ac.uk/berrill/ 
Holstein, J. A. \& Gubrium, J. F. (2004). The active interview. In D. Silverman (Ed), Qualitative research: Theory, method and practice, (pp.140-61). London: Sage.

Kukulska-Hulme, A. (2002). Cognitive, ergonomic and affective aspects of PDA use for learning. Presented at the European Workshop on Mobile and Contextual Learning, University of Birmingham, 20-21 June. [viewed 3 July 2006] http: / / iet.open.ac.uk/pp/a.m.kukulskahulme/PDAsBirmingham.htm

Kukulska-Hulme, A. \& Pettit, J. (2006). Practitioners as innovators: Emergent practice in personal mobile teaching, learning, work and leisure. Paper presented at mLearn 2006, Banff, Canada, 22-25 October. [verified 17 Jan 2007] http:/ / kn.open.ac.uk/public/document.cfm?docid=8901

Lilley, A. (2006). Public is the new private for the MySpace generation. Media Guardian, 20 March, p.8. [verified 16 Feb 2007] http: / / media.guardian.co.uk/ site/ story /0,1734638,00.html

McMahon, M. \& Pospisil, R. (2005). Laptops for a digital lifestyle: Millennial students and wireless mobile technologies. In Balance, Fidelity, Mobility: Maintaining the Momentum? Proceedings ASCILITE 2005. Brisbane, 4-7 December. [viewed 19 June 2006] http:/ / www.ascilite.org.au/ conferences / brisbane05/blogs/proceedings / 49_McMahon\%20\&\%20Pospisil.pdf

Miller, J. \& Glassner, B. (2004). The 'inside' and the 'outside': Finding realities in interviews. In D. Silverman (Ed.), Qualitative research: Theory, method and practice, (pp.125-139). London: Sage.

Mitchell, L. (2006). Adventures in blog land. The Age. [viewed 18 July 2006] http: / / www.theage.com.au/news/ education-news/adventures-inblogland / 2006/07/01/1151174437503.html

Mulholland, P., Collins, T. \& Zdrahal, Z. (2005). Bletchley Park Text: Using mobile and semantic web technologies to support the post-visit use of online museum resources. Journal of Interactive Media in Education (Portable Learning: Experiences with Mobile Devices. Special Issue). [viewed 14 July] http:/ /jime.open.ac.uk/2005/24/mulholland-2005-24-t.html

Owen, J. (2005). London bombing pictures mark new role for camera phones. National Geographic News. [viewed 15 June 2006]

http:/ / news.nationalgeographic.com/news/2005/07/0711_050711_londoncell.html

Pettit, J. (1998). Second generation good, third generation better? In A. Szücs and A. Wagner (Eds.), Universities in a Digital Era, (pp. 248-51). Conference proceedings of the European Distance Education Network, Bologna.

Prensky, M. (2005). What can you learn from a cell phone? Almost anything! Innovate, 1(5). [viewed 3 July 2006] http: / / www.innovateonline.info/index.php?view $=$ article\&id $=83$

Rogers, E. M. (2003). Diffusion of innovations (5th ed.). New York: Simon and Schuster. 
Schwabe, G. \& Göth, C. (2005). Mobile learning with a mobile game: Design and motivational effects. Journal of Computer Assisted Learning, 21(3), 204-16. [verified 16 Feb 2007] http:/ / www.ifi.unizh.ch/im/imrg/fileadmin/publications/JCA_128.PDF

Sharples, M., Corlett, D. \& Westmancott, O. (2002). The design and implementation of a mobile learning resource. Personal and Ubiquitous Computing, 6(3), 220-34. [verified 16 Feb 2007]

http:/ / www.eee.bham.ac.uk/sharplem/Papers/mobile\%20learning\%20puc.pdf

Tamminen, S., Oulasvirta, A., Toiskallio, K. \& Kankainen, A. (2004). Understanding mobile contexts. Personal and Ubiquitous Computing, 8(2), 135-43. [verified $16 \mathrm{Feb}$ 2007] http:/ / www.cs.helsinki.fi/u/oulasvir/scipubs/UMC_Puc2004_Oulasvirta.pdf.

Thornton, P. \& Houser, C. (2005). Using mobile phones in English education in Japan. Journal of Computer Assisted Learning, 21(3), 217-228.

Waycott, J. \& Kukulska-Hulme, A. (2003). Students' experiences with PDAs for reading course materials. Personal and Ubiquitous Computing, 7(1), 30-43.

Wray, R. (2006, 29 May). O2 trial finds mobile TV catches on with commuters. The Guardian. [viewed 6 July] http:/ / business.guardian.co.uk/ story/0,,1784974,00.html

This article received an Outstanding Paper Award at ASCILITE 2006, gaining the additional recognition of republication in AJET (with one minor correction). The reference for the Conference version is:

Pettit, J. \& Kukulska-Hulme, A. (2006). Going with the grain: Mobile devices in practice. In Markauskaite, L., Goodyear, P. \& Reimann, P. (Eds), Who's Learning? Whose Technology? Proceedings of the $23 \mathrm{rd}$ ASCILITE Conference (pp. 647-656). Sydney, 3-6 December. http: / / www.ascilite.org.au/conferences/sydney06/proceeding/ pdf_papers/p91.pdf

John Pettit, Institute of Educational Technology, The Open University, Walton Hall, Milton Keynes MK7 6AA, United Kingdom. Email: j.g.pettit@open.ac.uk.

Agnes Kukulska-Hulme, Institute of Educational Technology, The Open University, Walton Hall, Milton Keynes MK7 6AA, United Kingdom. Email: a.m.kukulska-hulme@open.ac.uk 